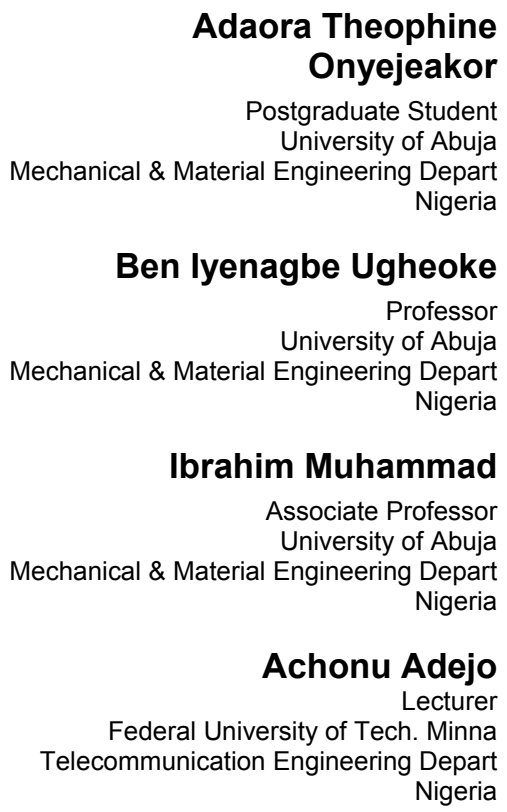

Achonu Adejo

Lecturer

Federal University of Tech. Minna Telecommunication Engineering Depart

Nigeria

\section{Production-time Evaluation Technique for Small Manufacturing Plants}

\begin{abstract}
Small manufacturing plants usually experience challenges of inefficiency and low production yields. These problems have previously been addressed using methods to redesign plant layouts and reduce distance between workstations. Futhermore, assessment techniques like the machine-distance matrix method have then been required to evaluate layout performance. However, these assessments that rely only on distance evaluation are severely limited. In this paper, a new model called Production-time evaluation is presented for evaluating production layout efficiency. It involves computing the estimated time for production at workstations, time for movement between workstations and number of units of a product manufactured. It is then applied on a case study in small furniture plant. The existing layout of the plant was extracted and the production processes for its three products were outlined. A new layout was designed and both layouts were compared using the Production-time methodology, revealing improvements in reduced production time and increased daily production capacity by up to $37 \%$ for a product.
\end{abstract}

Keywords: Plant layout, Optimization, Machine Distance matrix technique, Production, Mathematical Modelling.

\section{INTRODUCTION}

Small manufacturing plants make important contribution to the technology base and economy in every country. For these plants to operate successfully and profitably, their production processes must be efficiently designed and organised [1-3]. The factors influencing this include raw material management, quality of technology [4-6] and innovation [7]. Summarily, the way resources (man, material, equipment and space) are laid out and managed determines the quality of output achieved.

The situation in developing countries is that many small production plants are faced with challenges that limit their performance. They are usually designed without consideration for efficient plant layouts. In addition, during the production process, poor resource handling results in problems like crisscrossing of materials. Hence, these plants struggle with huge cost of production, inefficiencies, poor yields, unnecessary delays and low revenue generated $[8,9]$.

To address this problem, techniques are needed to improve manufacturing procedures. It is proven that if the challenges can be identified and analysed, then production optimization can be applied in the plants to improve their output. Using furniture manufacturing plants as a case study, optimization has been carried out to enhance productivity after inherent problems like unorganized process flows, poor documentation, poor handling /control of materials were identified. Significant impro-

Received: September 2020, Accepted: November 2020

Correspondence to: Adaora T. Onyejeakor

Mechanical and Materials Engineerig Department,

University of Abuja, Nigeria

E-mail:phinny09@gmail.com

doi: $10.5937 /$ fme2101186T

(C) Faculty of Mechanical Engineering, Belgrade. All rights reserved vements were achieved in the distance for travel of parts, material handling costs, machinery rearrangement, efficient utilization of space, safety, machinery and labour utilization and profitability $[9,10]$.List of other methods that have been applied in furniture manufacturing include computer modelling and simulation tools like Promodel, computerized relative allocation of facilities technique (CRAFT), development of matrices for process structure manufacturing and maintenance, formal methods for layout modelling, minimum product travel method and optimization methods like graph theory and genetic algorithm etc. The gains of these techniques include reduction in production cycles, idle times etc [11-14]. Some additional research works employing analytical and intelligent procedures are in [15-22]. Cost reduction is an important goal in manufacturing which is a key factor for sustainability of small to medium enterprises (SME) [23]. Reduction of cost helps to improve process control, waste elimination and improve profit margins. The common areas analysed for improvement and reduction of cost begin from the plant layout. The set-up and maintenance of machines also determine optimal batch sizes for a production run [24].

The emphasis of this research is on improving plant layouts to achieve more efficient production in small manufacturing plants. When an improved layout is designed for a plant, an assessment technique will be required to measure its performance. In this article, a new technique is presented for evaluation of small production plants, which uses production time as the key metric. The aim is to evaluate how long it takes for a unit of each product to be manufactured, from which daily production in the plant can be predicted. From this assessment, the economic viabilities from possible 
layouts of the plant under investigation can also be estimated. This methodology is an improvement over the popular distance-based metric [9], which considers only the distance between workstations as evaluation metric.The metric based on time captures not only the distance between, but also the speed of movement between workstations. The technique is applied with positive results on the production layout of a real furniture manufacturing plant that was chosen based on its size. This technique is therefore a practical methodology for improving production processes of furniture plants based on their plant layout and process design, leading to higher production yields.

\section{PREVIOUS RESEARCH}

Various techniques have been presented in literature for enhancing furniture plants. FlexSim is a simulation tool presented in [14] used to redesign a furniture plant. First of all, the raw material requirements were identified and were divided according to their weights. Furthermore, this information was used for an inventory category technique known as $\mathrm{ABC}$ analysis. This revealed the importance of each type of raw material. The second step was to understand the existing process sequence. At every processing stage, the timing required per process was captured using a stop clock. In this way, capacity planning for the new plant was determined. The third step involved creating the layout by considering the available space, process interrelation between two successive departments and the capacity required to achieve the desired output rate. Finally, after the layout design, simulation was carried out by the simulator. When observing the simulation result, the capacity of each workstation and the bottlenecking location were identified and decisions were made on how to revise the plant capacity [14].

In [24], the authors evaluated the layout of a plant which included workstations for cutting, drilling, sanding and joining operations. A conveyor/transport system was used to move the completed products to the storage point. A simulator was used to model the layout and find ways to improve processes, while the input methods considered includedusing lot sequences and batches. Microsoft project was used to examine the implications of scheduling practices on the production time for layout processes. The operational planning model created wasuseful in testing out weekly/biweekly production schedules and to evaluate new cuttings.

Authors in [25] showedthe application of System layout planning (SLP) method to efficiently establish the layout of a productive enterprise. The plant layout problems were generalised into five important elements according to SLP method. They are: a) Product (end product, raw material, machining components and projects). b) Quantity (amount of production supply, utilization or service workload). c)Route (i.e. plant layout diagram, process route diagram, process flow chart). d) Supporting service (tools, maintenance, propulsion, deliveries etc), and e) Time (when and how long the production is which includes the operating time of every procedure).

The methodology used in this article is an extension of the studiesin $[8,9]$,where the distance matrix method was used to evaluate three layout models for a furniture plant. This method involves computing the total distance travelled during production based on the distance between workstations and the number of movements between workstations. Improved layouts can be obtained by reducing the distances between workstations to prevent long areas of movement during production. The most effective layout was found to be the one with the smallest total distance travelled. This method also helped to address the problem of crisscrossing during production. However, a challenge with this technique is that it overlooks the time it takes to make a product and considers only the distance of travel.This limitation is overcome through the new evaluation methodologyfor plant layouts presented in the next section that considers the total time required to make a product and estimates the number of products that can be manufactured from a given layout.

\section{PRODUCTION-TIME EVALUATION METHODO- LOGY}

Some of the common stages involved in typical furniture production include design, selection of raw materials, shearing, drying, fabricating individual parts, polishing, painting and final assembly. During fabrication, the plant layout is important and determines the efficiency of the process. It entails how equipment and facilities within the plant are arranged physically. It specifies the parameters for the production lines, storage facilities and stores, which affect cycle time and performance. When optimized, the chances of production optimization are higher since materials will be handled in a better way and the various distances that equipment and operators move will reduce [14]. A good layout ensures proper utilization of the floor space, reduced material handling costs, reduced hazards to personnel, efficient utilization of labour and improved productivity [25].

Therefore, the technique proposed in this paper aims at ensuring a better evaluation of the layout in a Production plant. This will allow several layouts to be properly evaluated and aid the selection of the optimal layout that will enhance productivity.

\subsection{Comparison with Distance evaluation method}

There are several benefits in extending the distance matrix method in $[8,9]$ to develop the production time evaluation technique proposed in this article. The accuracy of analysis is improved since other parameters apart from distance are considered including:

- Time spent at workstation sites (no movement)

- Total time for production captured.

- Equipment for movement between workstations and their speed and its effect on total time of production.

- Combined analysis for different products as against only one product.

\subsection{Description of basic parameters}

For this research, a unit of operation is chosen for ease of analysis. Let $T_{u}$ be defined as a basic unit of typical 
time spent at a workstation daily. $T_{u}$ will obviously depend on the number of staff employed in the factory which determines the average time production activities are carried out per workstation. Therefore, $T_{u}$ will be considered variable for different production scenarios that will be evaluated. The more staff are hired for production process, the lesser time will be taken at each workstation. $T$ is also defined as the total time taken daily on manufacturing at the factory. If $T^{p}$ is the time taken daily on each product being manufactured, then $T$ is the sum of $T^{p}$ for all products. $T^{p}$ is further broken down into two:

- Time spent daily at workstations or workspaces, $T_{w}^{p}$

- Time taken daily during production to move between workstations or workspaces, $T_{w}^{p}$ where $p$ is the product under consideration.

Therefore:

$$
\begin{aligned}
& T=T^{a}+T^{b}+T^{c}+T^{y}+T^{z} \\
& =\left(T_{w}^{a}+T_{m}^{a}\right)+\left(T_{w}^{b}+T_{m}^{b}\right)+\left(T_{w}^{c}+T_{m}^{c}\right)+\ldots \\
& +\left(T_{w}^{y}+T_{m}^{y}\right)+\left(T_{w}^{z}+T_{m}^{z}\right)
\end{aligned}
$$

where $\{a, b, c, \ldots, y, z\}$ are the identifiers for all products being manufactured.

\subsection{New equation for daily Time spent on a Product, $T^{p}$}

As earlier defined, for any given product $p$, the total daily time spent on $p$ is considered as:

$$
T^{p}=T_{w}^{p}+T_{m}^{p}
$$

Assuming that for $p$, there are ' $a$ ' workstations and storage points, therefore $T_{w}^{p}$ will be composed of ' $a$ ' values which can be summarized thus:

$$
T_{w}^{p}=\sum_{i=1}^{a} T_{i}^{p}
$$

Similarly, the time of movement of $p, T_{m}^{p}$, will be composed of $a-1$ steps of movement between each of the workstation pairs from the beginning till the end. Therefore, $T_{m}^{p}$ is given as:

$$
T_{m}^{p}=\sum_{j=1}^{a-1} N_{j}^{p} T_{j}^{p}
$$

where $N_{j}^{p}$ is the number of movements at step $j$ in producing product $p$ and $T_{j}^{p}$ is the time to move materials at $\operatorname{step} j$.

However, $T_{j}^{p}$ which is time of physical movement can be considered to depend on both distance and velocity since Time $=\frac{\text { Distance }}{\text { Velocity }}$. Expressing $T_{j}^{p}$ in terms of distance and velocity gives:

$$
T_{m}^{p}=\sum_{j=1}^{a-1} N_{j}^{p} T_{j}^{p}=\sum_{j=1}^{a-1} N_{j}^{p} \frac{D_{j, j+1}^{p}}{V_{j}}
$$

where $D_{j, j+1}^{p}$ is the distance between the $j$ th and the $(j+$ 1) thworkstation and $V_{j}$ is the estimated velocity of movement of the material handling equipment at step $j$.

Therefore, the total time, $T^{p}$ is given by:

$$
T^{p}=\sum_{i=1}^{a} T_{j}^{p}+\sum_{j=1}^{a} N_{j}^{p} \frac{D_{j, j+1}^{p}}{V_{j}}
$$

(6) will be generated for each product and the total daily time for all production processes in the plant can be obtained by summing thetotal time computed for each product.

For ease of analysis, $T_{i}^{p}$ and $V_{j}$ in (6) will be expressed in termsof $T_{u}$, the basic unit of production time.

\subsection{Equation for Number of Units of a Product}

A useful derivation from (6) is the estimated number of units of a particular product that can be manufactured in the plant within a duration of time. The number of units of a product ' $a$ ', $U_{a}$ is given as:

$$
U_{a}=\frac{h_{d} \times d}{T^{a}}
$$

where $h_{d}$ is the number of hours of work in a day, $d$ is the number of work days in a week and $T^{a}$ is the total time spent on product ' $a$ ' in a day as given by (6).

\section{PLANT LAYOUT AND PROCESS FLOW IN EXA- MINED FURNITURE PLANT: A CASE STUDY}

\subsection{Description of Plant and Production Processes}

The case study is the Production area of a furniture manufacturing plant in Abuja, Nigeria. During inspection, data collected included Products manufactured, Machine positions \& distance travelled, Materials Handling Equipment \& Flow Paths, Storage space and Operations flow \& process times. The threeproducts considered that are manufactured in the plant are Chairs, Beds and Cabinets. The total production area of the plant layout is approximately $1,110.4 \mathrm{~m}^{2}$. In the plant, two different types of materials, i.e.local wood and melamine faced chipboard (MFC) are used for production.

Plant Layout Measurements of the available space were made and setup to show the position of workstation locations as shown in Figure 1. This figure shows both the plant layout and process flows for the three products. The first product considered is theChair. The arrows show how the movements are carried out from one workstation to another in succession till the final storage point. First of all, local woods are taken to the drying section to dry out any water content in them and also betreated of pests. The woods are then taken to the cutting machine where they are cut into different sizes according to specifications, then to the planning machine where their surfaces are smoothened, flattened 
and their thickness reduced. Next, they are moved to the thicknesser machine to add thickness to them if needed, then to the turning machine where theyare carved into symmetrical objects and different shapes. They are next taken to the sandpaper section for spraying, are allowed to dry and then taken to the upholstery section and the final storage point.

The process description for beds is presented next. The MFC are taken from the warehouse to the cutting machine to be cut according to specifications, then to the edge banding machine to seal up the edges of the board. The next process is to drill holes on the boards at the drilling machine point, then the boards are taken to the coupling section where dowels are used. They are then moved to the local wood section where the inner part of the beds ismade using local woods, then to the upholstery section where the local wood is padded for comfort. Finally, they are moved back to the cleaning section, where proper cleaning is done and then thefabricated bed is moved to thestorage point, ready for dispatch.

The process of making a cabinet is similar to that of a bed because similar boards are used. In this case, MFC aretaken to the cutting machine from the warehouse andcut according to specifications, then they are taken to the edge banding machine to seal up the rough edges. The next process is to drill holes on the boards at the drilling machine point, then the boards are taken to the coupling section where dowels are used at the joints, then to the cleaning section and finally to the storage point.

For each product, the number of movements between workstations are noted. Materials and parts in the plant are moved by trolleys, forklifts and by hands, which are presented in Table 1.

\section{Table 1. Material Handling equipment and Dimensions}

\begin{tabular}{|l|c|c|}
\hline Equipment & Dimensions (m) (Length x Width) & Quantity \\
\hline Forklift & $4.50 \times 1.40$ & 1 \\
\hline Forklift & $3.80 \times 1.20$ & 2 \\
\hline Hand & & \\
\hline Trolley & $2.40 \times 0.80$ & 2 \\
\hline Trolley & $2.70 \times 1.20$ & 3 \\
\hline
\end{tabular}

\subsection{Improved Layout}

An improved production layout was designed generating processes where the distances between workstations are significantly reduced, thereby reducing the time taken to produce the different items. Based on the existing layout and the process flows for the three items considered, the following decisions are made to improve the existing layout in Figure 1: a) The door section is moved from the fourth compartment after the drying section to the first. b) The local wood section is moved from the third compartment after the drying section to the second. c) The sandpaper section and the spraying room are moved from the first compartment after the drying section to the third. d) The Upholstery section is moved from the second compartment after the drying section to the fourth.

Generally, the new layout arrangement was specifically carried out after careful consideration of the distances between workstations in the existing layout at use in the factory. Since the production of chairs involved the highest movements between workstations, the new layout is developed to favour the reduction of connection lines for chair production with a careful consideration on the impact on production of beds and cabinets. The improved layout and process flow diagram is shown in Figure 2.

\section{EVALUATION USING TIME-BASED METHOD}

For analysis and comparison of the two layouts, the production process of the three products (Chairs, Beds and Cabinets) are analysed. This is based on the proposed Mathematical framework assessing their production time. The parameter considered is the time it takes to make a single unit of each product. This time parameter can be used to estimate the number of products that can be manufactured and by extension the amount of revenue that can be received. For each material movement in the process flow as shown in Figures 1 and 2 for the three products, the equipment used for movement as well as the number of movements in each stepare shown in Table 2.

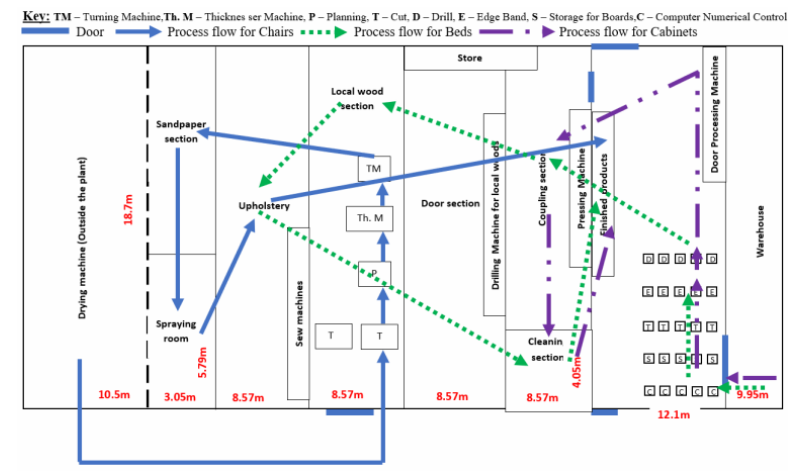

Figure 1. Current Plant layout and Process flows

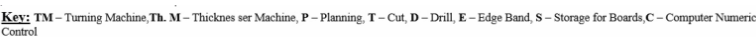

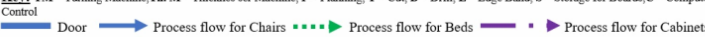

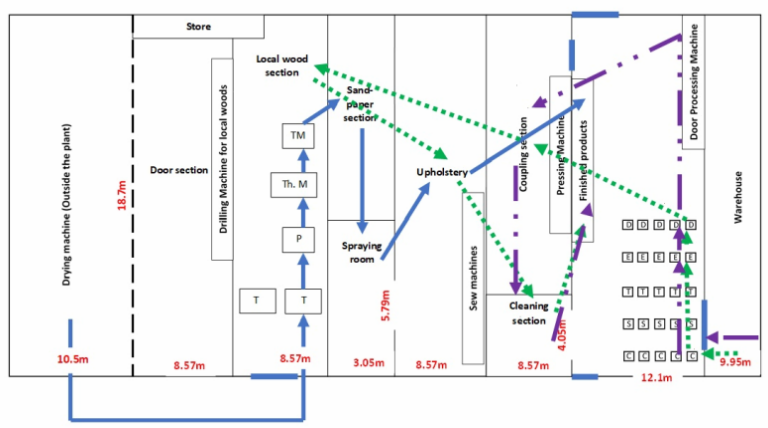

Figure 2. Modified Plant layout and Process flows

Table 2. Equipment list for each Movement step and number of movements per step

\begin{tabular}{|l|c|c|c|}
\hline $\begin{array}{c}\text { Movement } \\
\text { Step }\end{array}$ & $\begin{array}{c}\text { Chair } \\
\text { production }\end{array}$ & $\begin{array}{c}\text { Bed } \\
\text { production }\end{array}$ & $\begin{array}{c}\text { Cabinet } \\
\text { production }\end{array}$ \\
\hline 1 & Forklift(1) & Forklift(1) & Forklift(2) \\
\hline 2 & Hand(2) & Hand(3) & Hand(1) \\
\hline 3 & Hand(1) & Hand(3) & Hand(1) \\
\hline 4 & Hand(1) & Trolley(3) & Trolley(1) \\
\hline 5 & Trolley(1) & Trolley(1) & Hand(1) \\
\hline 6 & Hand(1) & Trolley(2) & Trolley(1) \\
\hline 7 & Hand(1) & Trolley(2) & \\
\hline 8 & Trolley(1) & Trolley(3) & \\
\hline
\end{tabular}




\subsection{Production time for Chairs}

Based on the description of (2), the time spent daily to produce a chair, $T^{c}$ is given by:

$$
T^{c}=T_{w}^{c}+T_{m}^{c}
$$

where $T_{w}^{c}$ is the total daily time spent at all workstations used for the chair and $T_{m}^{c}$ is the total daily time spent during movement.

To obtain $T_{w}^{c}$ which is based on (3), the typical total time spent at any workstation in a day is considered as a basic unit of time given by $T_{u}$. For the production of chairs which has 9 workstations, the following were observed: 1 Chair is produced every week (6 working days). Therefore, the equivalent quantity of Chair produced in a day is $\frac{1}{6}$. All workstations apart from Upholstery take almost equal time equivalent to $T_{u}$, i.e eight workstations take time $8 T_{u}$. Time for Upholstery, $T_{u s}^{c}$ takes three times the time in each of the other workstations, i.e $3 T_{u}$. Therefore:

$$
T_{w}^{c}=\frac{1}{6} \times\left(3 T_{u}+8 T_{u}\right)=\frac{11 T_{u}}{6}
$$

To obtain $T_{m}^{c}$, (5) requires that during production, the equipment used for each movement between workstations as well the number of movements in each step should be noted. These are obtained from Table 2. (5) also specifies the estimated velocity of moving each equipment as a parameter to compute the time of movement. The estimated velocity for each movement equipment (Forklift, Trolley and Hand) can be expressed in terms of $T_{u}$, derived based on current information from the plant, as follows:

- It takes approximately 50 times less than $T_{u}$ (the time spent on one workstation) to move items in the forklift by $1 \mathrm{~m}$, therefore the velocity of movement with a forklift is $\frac{1}{T_{u} / 50}=\frac{50}{T_{u}} \mathrm{~m} / \mathrm{s}$

- It takes approximately 30 times less than $T_{u}$ to move items in the trolley by $1 \mathrm{~m}$, therefore the velocity of movement with a trolley is $\frac{30}{T_{u}} \mathrm{~m} / \mathrm{s}$

- It takes approximately 15 times less than $T_{u}$ to move items by hand for $1 \mathrm{~m}$, therefore the velocity of movement by hand is $\frac{15}{T_{u}} \mathrm{~m} / \mathrm{s}$

These are summarized in Table 3. $T_{m}^{c}$ is computed from (5) by using these derived velocities, extracting the number of movements from Table 2. and using the distance between workstations obtained from Figure 1 (for the current plant layout) and Figure2 (for the improved layout).

Table 3. Velocity of Movement for Equipment

\begin{tabular}{|l|c|}
\hline Equipment & Velocity(m/s) \\
\hline Forklift & $50 / T_{u}$ \\
\hline Trolley & $30 / T_{u}$ \\
\hline Hand & $15 / T_{u}$ \\
\hline
\end{tabular}

\subsection{Production time for Beds}

This is derived using a similar process to the chairs. $T^{b}$, $T_{w}^{b}$ and $T_{m}^{b}$ represent the time spent daily to produce a bed, the total daily time spent at all workstations used for the bed and the total daily time spent in movement during bed production, respectively.To produce beds, 9 workstations are involved as shown in Figures 1 and 2. The following are noted from current production: 2 beds are produced daily, all workstations related to bed production take almost the same amount of time equivalent to $0.5 T_{u}$ except coupling, i.e eight workstations take time equivalent to $4 T_{u}$. Coupling time takes thrice the time in each of the other workstations, i.e $1.5 T_{u}$. Therefore:

$$
T_{w}^{b}=2 \times\left(4 T_{u}+1.5 T_{u}\right)=11 T_{u}
$$

\subsection{Production time for Cabinets}

Similarly, $T^{a}, T_{w}^{a}$ and $T_{m}^{a}$ are derived for the case of cabinets. To produce Cabinets, Figures 1 and 2 show that 6 workstations are involved. The following information is noted: 6 cabinets are produced daily. All workstations related to Cabinet production take almost the same amount of time equivalent to $0.5 T_{u}$, except Coupling and Cleaning, i.e four workstations take $2 T_{u}$. Coupling time takes twice the time in each of the other workstations, $T_{u}$ and Cleaning time, takes 1.5 times the time in each of the other workstations, i.e. $0.75 T_{u}$. Therefore:

$$
T_{w}^{a}=6 \times\left(2 T_{u}+T_{u}+0.75 T_{u}\right)=22.5 T_{u}
$$

\subsection{Analysis of Time for movement between work- stations}

$T_{m}^{c}, T_{m}^{b}$ and $T_{m}^{a}$ are defined as the total movement time during the processes of making chairs, beds and cabinets respectively. This refers to the three movement paths shown in Figure 1 (for the current layout) and Figure 2 (for the modified layout). Recall that $T_{u}$ is the basic time unit that relates both time spent at workstations and during movements. The value of $T_{u}$ is considered to depend on factors like the number of staff at a workstation and quality of equipment. For example, if the number of staff at a workstation increases or if more sophisticated equipment are used at a workstation, then $T_{u}$ will likely decrease. However, the scope of this research does not cover analysis of the impact from labour and equipment quality. Rather, the focus is to investigate the effect of $T_{u}$ on $T$, (total time of daily production activities defined in (1).Consequently, the basis for analysis in this work is to vary $T_{u}$ and study the resulting effect on $T$. First of all, the realistic range of values for $T_{u}$ is calculated. From (1), $T$ for this plant is:

$$
\begin{aligned}
& T_{m}^{c}, T=\left(T_{w}^{a}+T_{m}^{a}\right)+\left(T_{w}^{b}+T_{m}^{b}\right)+\left(T_{w}^{c}+T_{m}^{c}\right)= \\
& =\frac{11 T_{u}}{6}+11 T_{u}+11 T_{u}+T_{m}^{a}+T_{m}^{b}+T_{m}^{c}
\end{aligned}
$$


Let $T_{m}=T_{m}^{a}+T_{m}^{b}+T_{m}^{c}$. Therefore:

$$
T=35.33 T_{u}+T_{m}
$$

$T$, the total time spent daily on production in the factory is 9 hours $(9 \times 60)$ minutes excluding a 1 hour break. Therefore the range of possible values for $T_{m}$ are:

$$
T_{m}=T-35.33 T_{u}=9 \times 60-35.33 T_{u}
$$

Figure 3 shows two plotsgenerated from (14) as $T_{u}$ is varied according to the range $2 \leq T_{u} \leq 18$.

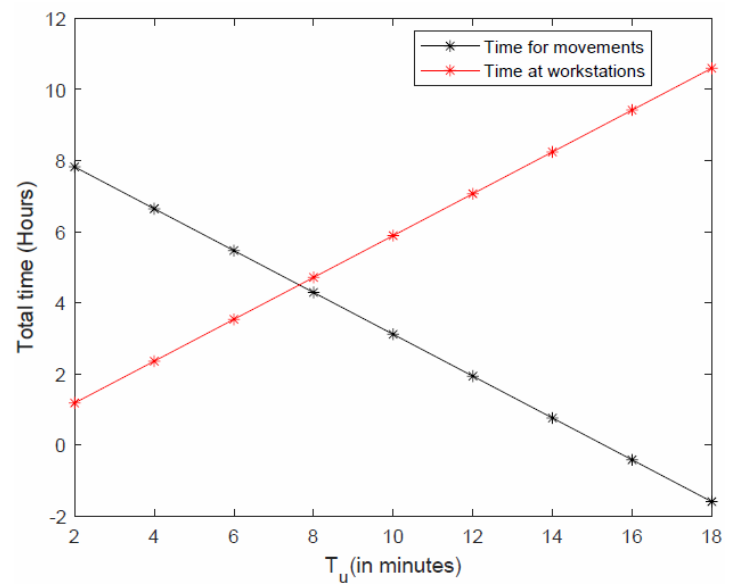

Figure 3. Total time for activities at workstations \& during movements based on available working time in a day

The first plot is of $35.33 T_{u}$ in hours versus $T_{u}$ in minutes to show the relationship between total time spent at workstations and $T_{u}$. The second plot is of $T_{m}$ in hours versus $T_{u}$ in minutes which gives the result for time spent in movement between workstations. The plots have different slopes because both parameters plotted are constrained by the fixed daily time for work $(T)$, hence the more time is spent at workstations, the less time is spent during movements and vice versa. For analysis and optimization, it is important to select a realistic range of values for $T_{u}$. From the above graph, the realistic range of $T_{u}$ is obtained when $T_{m}>0$. Therefore, the selected range of $T_{u}$ for analysis in this research is $2 \leq T_{u} \leq 14$.

\section{RESULTS AND DISCUSSION}

Having isolated the realistic range for the unit of time $\left(T_{u}\right),(13)$ is expanded based on (6) as:

$$
\begin{aligned}
T=35.33 T_{u} & +\sum_{j=1}^{8} N_{j}^{c} \frac{D_{j, j+1}^{c}}{V_{j}^{c}}+\sum_{j=1}^{8} N_{j}^{b} \frac{D_{j, j+1}^{b}}{V_{j}^{b}}+ \\
& +\sum_{j=1}^{6} N_{j}^{a} \frac{D_{j, j+1}^{a}}{V_{j}^{a}}
\end{aligned}
$$

where $D_{j, j+1}^{c}, D_{j, j+1}^{b}, D_{j, j+1}^{a}$ refers to the distance between the $j$ th and $(j+1)$ th workstations in sequence for the manufacturing processes of chairs, beds and cabinets respectively as obtained in Figures 1 and 2 . $T_{\text {existing }}=51.73 T_{u}, \quad N_{j}^{b}, \quad N_{j}^{a}$ are the number of movements at step juring the production of chairs, beds and cabinets respectively as outlined in Table 2 . $V_{j}^{c}, V_{j}^{b}, V_{j}^{a}$ are also the velocities (from Table 3) of equipment at step $\boldsymbol{j}$ during the production of chairs, beds and cabinets respectively as outlined in Table 2 . For the current layout in the plant shown in Figure 1, the total time for the three products is:

$$
\begin{aligned}
T=T_{\text {existing }}= & 35.33 T_{u}+T_{u}\left[\frac{35.6 m}{50 m / s}+\frac{2 \times 3.12 m}{15 m / s}\right]+ \\
& +\frac{3.12 m}{15 m / s}+\frac{3.12 m}{15 m / s}+\frac{14.38 m}{30 m / s}+ \\
& \left.+\frac{9.36 m}{15 m / s}+\frac{10.9 m}{15 m / s}+\frac{32 m}{30 m / s}\right]+ \\
& +T_{u}\left[\frac{21.38 m}{50 m / s}+\frac{3 \times 9 m}{15 m / s}+\frac{3 \times 3 m}{15 m / s}+\right. \\
& +\frac{3 \times 15.4 m}{30 m / s}+\frac{17.4 m}{30 m / s}+ \\
& +\frac{2 \times 17.92 m}{30 m / s}+\frac{2 \times 35.4 m}{30 m / s}+ \\
& \left.+\frac{3 \times 21.97 m}{30 m / s}\right]+T_{u}\left[\frac{2 \times 21.38 m}{50 m / s}+\right. \\
& +\frac{9 m}{15 m / s}+\frac{3 m}{15 m / s}+\frac{15.4 m}{30 m / s}+ \\
& +\frac{20.19 m}{15 m / s}+\frac{21.97 m}{30 m / s} \\
= & 54.72 T_{u} \\
T_{\text {existing }} &
\end{aligned}
$$

For the modified layout for the plant as depicted in Figure 2, the total time for the three products is:

$$
\begin{aligned}
T=T_{\text {existing }}= & 35.33 T_{u}+T_{u}\left[\frac{32.57 m}{50 m / s}+\frac{2 \times 3.12 m}{15 m / s}\right]+ \\
& +\frac{3.12 m}{15 m / s}+\frac{3.12 m}{15 m / s}+\frac{5.81 m}{30 m / s}+ \\
& \left.+\frac{9.36 m}{15 m / s}+\frac{5.81 m}{15 m / s}+\frac{14.85 m}{30 m / s}\right]+ \\
& +T_{u}\left[\frac{21.38 m}{50 m / s}+\frac{3 \times 9 m}{15 m / s}+\frac{3 \times 3 m}{15 m / s}+\right. \\
& +\frac{3 \times 15.4 m}{30 m / s}+\frac{20.19 m}{30 m / s}+ \\
& +\frac{2 \times 11.62 m}{30 m / s}+\frac{2 \times 14.34 m}{30 m / s}+ \\
& \left.+\frac{3 \times 21.97 m}{30 m / s}\right]+T_{u}\left[\frac{2 \times 21.38 m}{50 m / s}+\right. \\
& +\frac{9 m}{15 m / s}+\frac{3 m}{15 m / s}+\frac{15.4 m}{30 m / s}+ \\
& +\frac{20.19 m}{15 m / s}+\frac{21.97 m}{30 m / s} \\
= & 51.73 T_{u} \\
T_{\text {existing }} &
\end{aligned}
$$

Figure 4 gives a plot of the total time spent at workstations, for movement in the current layout and movement using the modified layout, all plotted against $T_{u}$. This was generated from (16) and (17). It can be 
observed that more time is spent at the workstations than during movement. There is also a significant time gain using the modified process over the current process. This result shows the proposed layout modifications will generally shorten the time required to manufacture products in the plant. The benefit is that within the time available for work in a day, more furniture can be produced and more revenue earned.

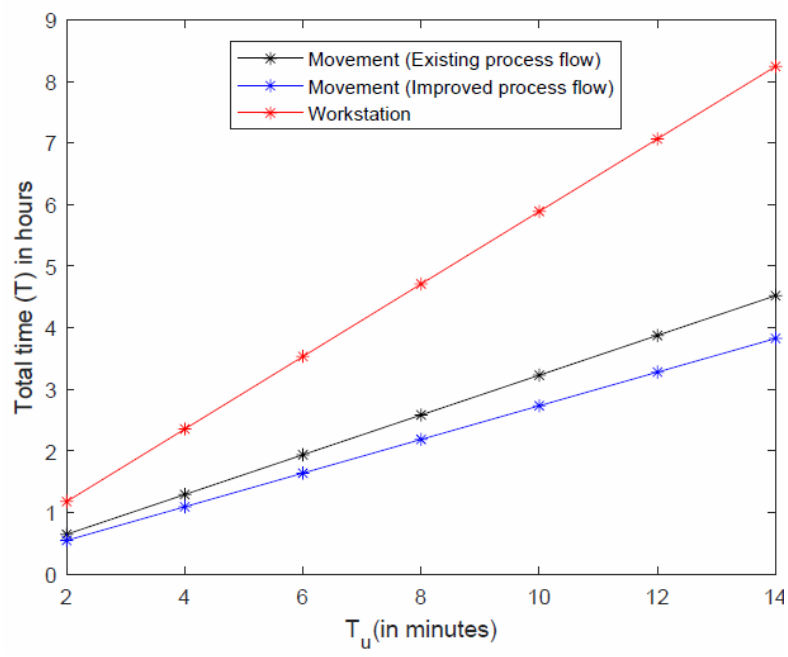

Figure 4. Comparison of time spent in movement and time spent at workstation processes

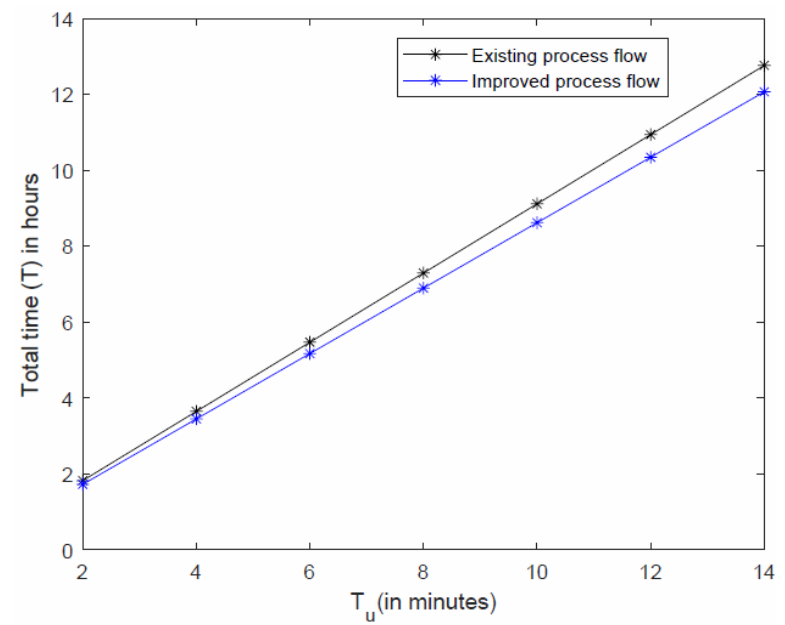

Figure 5. Comparison of total time spent according to current and improved layouts

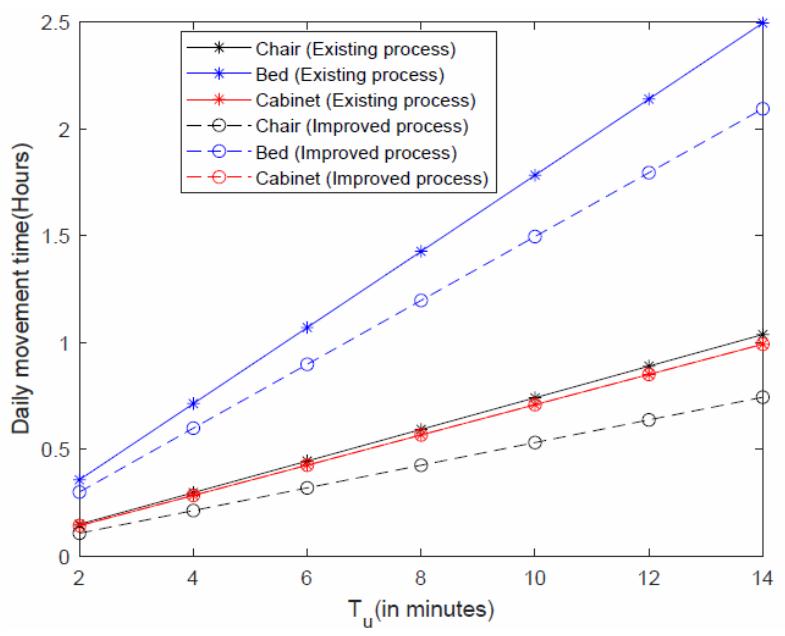

Figure 6. Comparison of time spent to make each product
Figure 5 shows the plots when the combined time at workstations and movements using the two layouts. Contribution from the improved movement in the new layout improves production efficiency. Figure 6 gives a comparison of the improvements obtained for the three products. Whilst there was no difference in the time in manufacturing cabinets, the times for producing chairs and beds were shortened significantly in the new layout.

Finally, (7) was applied to compute the estimated number of units of each product manufactured in a week, which is presented in Table $4 . h_{d}$ was set as 9 (i.e. for 9 hours of daily work), $d$ was set as 6 (i.e. for 6 days of work weekly). In all cases of $T_{u}$, the new layout gives a higher production for both chairs and beds with the maximum gain obtained when $T_{u}=14$ where $37 \%$ and $17 \%$ more units are made for Chairs and beds respectively.

Table 4. Estimated units of products made weekly.

\begin{tabular}{|c|c|c|c|c|}
\hline \multirow{2}{*}{$T_{u}$} & \multicolumn{2}{|c|}{ Chairs } & \multicolumn{2}{c|}{ Beds } \\
\cline { 2 - 5 } & Old layout & New layout & Old layout & New layout \\
\hline 2 & 302 & 395 & 100 & 111 \\
\hline 4 & 165 & 222 & 60 & 69 \\
\hline 6 & 113 & 154 & 43 & 49 \\
\hline 8 & 86 & 118 & 33 & 39 \\
\hline 10 & 70 & 96 & 27 & 32 \\
\hline 12 & 58 & 80 & 23 & 27 \\
\hline 14 & 50 & 69 & 20 & 23 \\
\hline
\end{tabular}

\subsection{Comparison between Distance matrix and pro- posed Evaluation method}

In this paper, presentation has been made on the evaluation of the current layout at a furniture plant and a new layout designed. The evaluation was carried out using a developed time-based technique.

This technique is able to provide useful information about which layout is more efficient.

This research has shown that in practical manufacturing activities, the information for distance alone is not sufficient to accurately describe the efficiency of operation.

This methodology therefore provides the following benefits in layout and process analysis over the methodology of distance matrix presented in $[8,9,26]$ :

- Showing how time is related to the distance between workstations.

- Considering the effect of material handling equipment on the time of production by considering the speed of each equipment.

- Considering the time spent at a workstation in the analysis.

- Considering the time spent in moving between workstations.

- Showing how the time spent in production can be analysed and enhanced.

- Shows how to compare different layouts based on how many products are manufactured.

- Generally, the new method provides more information and deeper analysis about the key factors affecting production in a plant. 


\section{CONCLUSION}

This research has presented a new technique for analysing production plants that captures the time to manufacture products in a holistic way. Furthermore, details of how this technique was applied to a case study furniture plant was shown. An initial visit was made to the plant and data of the production process was obtained including the current plant layout, the products fabricated and the detailed processes for fabrication of each product. This information was detailed using graphs, tables and discussed. Afterward, a new layout was designed for the plant based on some inefficiencies observed in the old layout. Finally, the new evaluation technique was also applied to the improved layout and result graphs show how improvement is achieved pictorially using the basic unit of time spent at each workstation.In addition, the estimated number of units for each product is computed, revealing as much as $37 \%$ more units of a product with the new layout.The limitation of this evaluation technique is that some other important parameters affecting production have not been considered in the mathematical model, but have been assumed. This includes the impact of labour and quality of equipment at workstations on the production time. A thorough cost analysis has also not been captured in the scope of this work. However, the mathematical model presented herein is scalable and all these parameters can be incorporated in future research.

\section{REFERENCES}

[1] D. Ajayi, "Nigerias industrial development: issues and challenges in the new millennium," WIT Transactions on Ecology and the Environment, vol. 150, pp. 711-723, 2011.

[2] O. Oguntoye, S. Evans, "Framing manufacturing development in africa and the influence of industrial sustainability," Procedia Manufacturing, vol. 8, pp. 75-80, 2017.

[3] J. Alao and E. Kuje, "Economics of small-scale furniture production in lafia metropolis, nasarawa state nigeria," Journal of Economics, vol. 3, no. 1, pp. 49-54, 2012.

[4] S. Paul, O. Chikelue, "The inclusive and sustainable industrial development policy: which way for nigeria?" Scientific Papers of the Legislation Institute of the Verkhovna Rada of Ukraine, no. 4, pp. 157-169, 2020.

[5] L. N. Chete, J. O. Adeoti, F. M. Adeyinka, and O. Ogundele, "Industrial development and growth in nigeria: Lessons and challenges," WIDER working paper, Tech. Rep., 2014.

[6] K. E. Uma, P. C. Obidike, C. O. Chukwu, C. Kanu, R. A. Ogbuagu, F. O. Osunkwo, and P. Ndubuisi, "Revamping the nigerian manufacturing sub-sector as a panacea for economic progress: Lessons from south korea," Mediterranean Journal of Social Sciences, vol. 10, no. 4, pp. 111-111, 2019.

[7] N. Ozigbo, "The sustenance of dynamics capabilities for improving firm performance: a study of selected furniture industry in abuja, nigeria," International Journal of Advanced Studies in Business Strategies and Management, vol. 4, no. 2, pp. 47-57, 2016.

[8] W. R. Nyemba, C. Mbohwa, and L. E. Nyemba, "Optimization of a plant layout and materials handling system for a furniture manufacturing company," in Proceedings of the World Congress on Engineering, vol. 2, 2016.

[9] W. R. Nyemba and C. Mbohwa, "Process mapping and optimization of the process flows of a furniture manufacturing company in zimbabwe using machine distance matrices," Procedia Manufacturing, vol. 8, pp. 447-454, 2017.

[10] Q. Zeng, X.-w. Dong, W.-1. Cao, "Research on furniture workshop layout optimization based on sha and slp,"in IE\&EM 2019. Springer, pp. 134-144, 2020

[11]B. John, J. James, and R. M. Rengaraj, "Analysis and optimization of plant layout using relative allocation of facilities technique," International Journal of Emerging Technology and Advanced Engineering, vol. 3, no. 8, 2013.

[12]P. Wilsten J and E. Shayan, "Layout design of a furniture production line using formal methods," Journal of Industrial and Systems Engineering, vol. 1, no. 1, pp. 81-96, 2007.

[13] N. A. A. S. M. S. R D Vaidya, P N Shende, Analysis plant layout for effective production," International Journal of Engineering and Advanced Technology (IJEAT), vol. 2, no. 3, 2013.

[14] S. M. Kadane and S. G. Bhatwadekar, "Manufacturing facility layout design and optimization using simulation," International Journal of Advanced Manufacturing Systems, vol. 2, no. 1, pp. 59-65, 2011.

[15]H. K. Banga, R. Kumar, P. Kumar, A. Purohit, H. Kumar, and K. Singh, "Productivity improvement in manufacturing industry by lean tool," Materials Today: Proceedings, 2020.

[16]C. Zhao and J. Li, "Analysis and improvement of multi-product assembly systems: An application study at a furniture manufacturing plant," International Journal of Production Research, vol. 52, no. 21, pp. 6399-6413, 2014.

[17] O. Oliveira, D. Gamboa, and P. Fernandes, "An information system for the furniture industry to optimize the cutting process and the waste generated," Procedia Computer Science, 2016.

[18] Antonelli, D., \& Bruno, G. "Dynamic distribution of assembly tasks in a collaborative workcell of humans and robots". FME Transactions, 47(4), 723-730, 2019.

[19] J. Vidal, M. Mucientes, A. Bugarin, and M. Lama, "An adaptive evolutionary algorithm for production planning in wood furniture industry," in 2006 International Symposium on Evolving Fuzzy Systems. IEEE, pp. 267-273, 2006.

[20] W. R. Nyemba and C. Mbohwa, "Modelling, simulation and optimization of the materials flow of 
a multi-product assembling plant," Procedia Manufacturing, vol. 8, pp. 59-66, 2017.

[21]T. Al-Hawari, A. Mumani, and A. Momani, "Application of the analytic network process to facility layout selection," Journal of manufacturing systems, vol. 33, no. 4, pp. 488-497, 2014.

[22] Belić, D., Kunica, Z., Opetuk, T., \& Đukić, G. (2018). Optimization of the plant layout in the production of the special transformers-case study. FME Transactions, 46(2), 285-290, 2018.

[23] M. O. Agwu \& C. I. Emeti,"Issues, challenges and prospects of small and medium scale enterprises (smes) in port-harcourt city,"European Journal of Sustainable Development,vol.3,no.1, 2014.

[24] R. G. Kyle and C. R. Ludka, "Simulating the furniture industry," in 2000 Winter Simulation Conference Proceedings (Cat. No. 00CH37165), vol. 2. IEEE, pp.1347-1350, 2000.

[25] L. Y. Chandra Shekhar T, "Improvement in layout design using slp of a small size manufacturing unit: A case study," IOSR Journal of Engineering (IOSRJEN), vol. 2, no. 10, pp. 1-7, 2012.

[26] S. Mehmet and A. Aminah, "Analysis and improvement of facility layout in a furniture factory: A case application,"Proceedings of the International Conference on Industrial Engineering and Operations Management, Dubai, UAE, March 10-12, pp. 436-4472020.

\section{ТЕХНИКА ПРОЦЕНЕ ВРЕМЕНА ПРОИЗВОДЊЕ КОД МАЛИХ ПРОИЗВОДНИХ ПРЕДУЗЕТА}

\author{
А.Т. Онијеакор, Б.И. Угеоке, И. Мухамад, \\ А. Адеџо
}

Мала производна предузећа најчешће се суочавају са изазовима неефикасности и малим приходима од производње. Овим проблемима истраживачи су се раније бавили изменом просторног распореда погона и смањењем међусобне удаљености радних станица. Процена перформанси просторног распореда погона вршила се методом матрице удаљености машина. Међутим, овакве методе имају ограничења. У раду се приказује нови модел који зовемо модел процене времена производње за процену ефикасности посторног распореда производних погона. Модел обухвата израчунавање процене времена производње у радним станицама, времена потребног за кретање производа између станица и број делова готовог производа. Модел је примењен код предузећа за производњу намештаја. Издвојен је просторни распоред погона и приказан је процес производње три производа. Израђен је пројекат новог распореда и упоређен са постојећим коришћењем методологије производног времена. Утврђено је да скраћење времена производње и повећање капацитета производње на дневном нивоу доводи до унапређења производње производа за 37\%. 